\title{
Loop diuretic use in patients with AKl: different severity, different response
}

\section{Yanfei Shen ${ }^{1 *}$ and Muying $\mathrm{Wu}^{2}$}

Recently, Dr. Bove and his colleagues performed an excellent systematic review [1] and reported that furosemide exhibited a neutral effect in acute kidney injury (AKI) treatment (odds ratio (OR) 1.14; 95\% CI 0.75 to 1.72). Despite being well designed, several limitations should be noted. First, the potential heterogeneity needs to be addressed. In this meta-analysis, three different interventions were combined in the control group, including placebo, continuous furosemide infusion, and torasemide administration. However, from a clinical aspect, comparability of therapeutic strategies is a prerequisite for a meta-analysis. Simply taking all these interventions as one control treatment is inappropriate and difficult to interpret for clinical meaning, despite the heterogeneity not being significant $\left(\mathrm{I}^{2}=0\right)$. Second, the effect of furosemide in AKI remains inconsistent. We noticed that the associations between poor outcomes and furosemide were more frequently reported in cohorts with higher serum creatinine $(\mathrm{sCr})(3.8 \mathrm{mg} / \mathrm{dl}[2], 3.3 \mathrm{mg} / \mathrm{dl}$ [3]) while insignificant in patients with mild AKI $(1.8 \mathrm{mg} / \mathrm{dl}$ [4]). Considering that fluid accumulation is a common issue in AKI, we speculate that patients with mild AKI are more likely to respond to furosemide challenge and the side effects of furosemide, such as oxidative stress [5], may be overwhelmed by the reduced fluid accumulation. In the current comparison, we performed a subgroup analysis according to different control treatments (Additional file 1). In all four studies using placebo as control (Cantarovich [6], Cantarovich [7], Kleinknecht [8], and Shilliday [9]), all the patients were described as having acute kidney failure (which indicates severe AKI) and the pooled effect was insignificant (OR 0.93 ; $95 \%$ CI 0.54 to 1.59 ; $p=0.78$ ). However, in another four studies using continuous furosemide infusion as control treatment, only one study (Brown [10]) was reported as ARF, and an extremely high dose of furosemide was used in this study $(1000 \mathrm{mg} / 24 \mathrm{~h}$, bolus vs
$3000 \mathrm{mg} / 24 \mathrm{~h}$, continuous). The severity of AKI in another three studies $(\mathrm{sCr} 1.4 \mathrm{mg} / \mathrm{dl}$ in Kunt [11], $2.1 \mathrm{mg} / \mathrm{dl}$ in Schuller [12], and $1.3 \mathrm{mg} / \mathrm{dl}$ in Shah [13]) was mild and when excluding these studies, the pooled outcome showed that continuous furosemide infusion was associated with lower mortality (OR 3.82; 95\% CI 1.30 to $11.28 ; p=0.024$ ). Thus, we think combining different treatment strategies as control treatment may cause biased conclusions. Finally, this is an enlightening study, and further investigations regarding whether continuous furosemide therapy could reduce the mortality rate in AKI patients are needed.

\section{Additional file}

Additional file 1: Figure S1. Subgroup meta-analysis according to different interventions of the control group. (TIF 776 kb)

\begin{abstract}
Abbreviations
AKI: Acute kidney injury; ARF: Acute renal failure; OR: Odds ratio; sCr: Serum creatinine
\end{abstract}

Availability of data and materials

Data sharing not applicable to this article as no datasets were generated or analyzed during the current study.

Authors' contributions

YS came up with the questions and MW is responsible for writing. Both authors read and approved the final manuscript.

Ethics approval and consent to participate

Not applicable.

Consent for publication

Not applicable.

Competing interests

The authors declare that they have no competing interests.

\footnotetext{
* Correspondence: snow.shen@hotmail.com

'Intensive care unit, Dongyang People's Hospital, NO.60 Wuning West Road,

Jinhua City, Zhejiang 322100, People's Republic of China

Full list of author information is available at the end of the article
}

(c) The Author(s). 2018 Open Access This article is distributed under the terms of the Creative Commons Attribution 4.0 International License (http://creativecommons.org/licenses/by/4.0/), which permits unrestricted use, distribution, and reproduction in any medium, provided you give appropriate credit to the original author(s) and the source, provide a link to the Creative Commons license, and indicate if changes were made. The Creative Commons Public Domain Dedication waiver (http://creativecommons.org/publicdomain/zero/1.0/) applies to the data made available in this article, unless otherwise stated. 


\section{Publisher's Note}

Springer Nature remains neutral with regard to jurisdictional claims in published maps and institutional affiliations.

\section{Author details}

'Intensive care unit, Dongyang People's Hospital, NO.60 Wuning West Road, Jinhua City, Zhejiang 322100, People's Republic of China. ${ }^{2}$ Intensive care unit, Yiwu Tianxiang East Hospital, NO.188 Huancheng South Road, Yiwu City,

Zhejiang, People's Republic of China.

Received: 29 May 2018 Accepted: 18 June 2018

Published online: 19 August 2018

\section{References}

1. Bove T, Belletti A, Putzu A, et al. Intermittent furosemide administration in patients with or at risk for acute kidney injury: meta-analysis of randomized trials. PLoS One. 2018;13(4):e0196088.

2. Mehta RL, Pascual MT, Soroko S, et al. Diuretics, mortality, and nonrecovery of renal function in acute renal failure. JAMA. 2002;288(20):2547-53.

3. Wu VC, Lai CF, Shiao CC, et al. Effect of diuretic use on 30-day postdialysis mortality in critically ill patients receiving acute dialysis. PLoS One. 2012;7(3):e30836.

4. Bagshaw SM, Gibney RTN, Kruger P, et al. The effect of low-dose furosemide in critically ill patients with early acute kidney injury: a pilot randomized blinded controlled trial (the SPARK study). J Crit Care. 2017;42:138-46.

5. Silbert BI, Ho KM, Lipman J, et al. Does furosemide increase oxidative stress in acute kidney injury? Antioxid Redox Signal. 2017;26(5):221-6.

6. Cantarovich F, Fernandez JC, Locatelli A, Perez Loredo J: Frusemide in high doses in the treatment of acute renal failure. Postgrad Med J 1971; 47(Suppl):13-17.

7. Cantarovich F, Galli C, Benedetti L, Chena C, Castro L, Correa C, Perez Loredo J, Fernandez JC, Locatelli A, Tizado J: High dose frusemide in established acute renal failure. Br Med J 1973;4(5890):449-450.

8. Kleinknecht D, Ganeval D, Gonzalez-Duque LA, Fermanian J: Furosemide in acute oliguric renal failure. A controlled trial. Nephron 1976;17(1):51-58.

9. Shilliday IR, Quinn KJ, Allison ME: Loop diuretics in the management of acute renal failure: a prospective, double-blind, placebo-controlled, randomized study. Nephrol Dial Transplant 1997:12(12):2592-2596.

10. Brown CB, Ogg CS, Cameron JS: High dose frusemide in acute renal failure: a controlled trial. Clin Nephrol 1981:15(2):90-96.

11. Kunt AT, Akgun S, Atalan N, Bitir N, Arsan S: Furosemide infusion prevents the requirement of renal replacement therapy after cardiac surgery. Anadolu Kardiyol Derg 2009;9(6):499-504.

12. Schuller D, Lynch JP, Fine D: Protocol-guided diuretic management: comparison of furosemide by continuous infusion and intermittent bolus. Crit Care Med 1997;25(12):1969-1975.

13. Shah RA, Subban V, Lakshmanan A, Narayanan S, Udhayakumaran K, Pakshirajan B, Krishnamoorthy J, Latchumanadhas K, Janakiraman E, Mullasari AS: A prospective, randomized study to evaluate the efficacy of various diuretic strategies in acute decompensated heart failure. Indian Heart J 2014:66(3):309-316. 